\title{
Narratives of Home on the Fringe of Tehran: The Case of Shahriar County
}

\author{
Saeed Dalil \\ Independent scholar \\ saeed.dalil@gmail.com
}

Barend Wind

Assitant Professor, Department of Planning, University of Groningen, Groningen, the Netherlands

b.j.wind@rug.nl

\author{
Abolfazl Meshkini \\ Associate Professor, Department of Geography and Urban Planning, \\ Tarbiat Modares University, Tehran, Iran \\ meshkini@modares.ac.ir \\ Jafar Javan \\ Professor, Department of Geography, Ferdowsi University of Mashhad, \\ Mashhad, Iran \\ jjavan@um.ac.ir
}

\begin{abstract}
This paper focuses on the notion of home as a narrative of one's lived experience that clashes with planners' understanding of housing and housing policies, using as a case study Shahriar County, located on the western fringe of the metropolitan area of Tehran. Following Heidegger, the feeling of home is a fundamental aspect of human existence. From this perspective, housing policies and spatial planning impact the sense of home in a geographical context. The empirical analysis is based on an overview of institutional changes since the Islamic Revolution in 1979, and interviews with inhabitants of Shahriar. The results indicate that Iran has developed a particular form of neoliberal, speculative model of urban development, in which urban segregation and seclusion and uneven regional development are noteworthy. Consequently, the
\end{abstract}


sense of home is structurally undermined on the metropolitan fringe, generating a feeling of living on the edge of the world.

\section{Keywords}

home - state mode of production (SMP) - neoliberal urbanism - urban fringe Tehran

\section{Introduction}

In post-devolutionary planning systems, spatial planning paves the way for neoliberal urbanism and creative destruction (see Haughton, 23o; Peck, Theodore, and Brenner 2009, 2013). As stated by Taşan-Kok, rather than emphasizing land-use rules and practices, neoliberal planning, the apparatus for neoliberal urbanism, tends to strategic neoliberal processes. The outcome blurs the boundary between the public and the private ushering the dominance of creative destruction in cities. This state of affairs provide the context for asymmetrical power relations between different societal groups (see Harvey 2005, 69-81). In this connection, Harvey (1985) argues that the state has an active regulatory role in the progression of neoliberal project (see idem 1989, 16). In actually existing neoliberalism (see Brenner and Theodore 2002), the state isolates itself from its socio-political context, thereby defining new regulations, in order to reconfigure its institutional apparatus (Bruff). Neoliberalism, in spite of its contradictions (Harvey 2005), has been able to maintain its existence throughout its evolutionary trajectories. These paths mainly involve high degrees of state intervention to "impose versions of market rule" (Theodore, Peck, and Brenner, 16). As for the spatial dimension, neoliberal urbanism, an expressive form of the neoliberalizing process, provides analytical tools to understand neoliberalism since cities are the locus of creative destruction. Theodore, Peck, and Brenner introduce moments of destruction such as the "[m]arginalization of 'home-grown' solutions to localized market and governance failures" or "performative discourses of urban disorder." They suggest that the neoliberal response to these problems would be creative moments such as the "imposition of decontextualized 'best practice' models derived from extrajurisdictional contexts" and "entrepreneurial discourses and representations focused on urban revitalization, reinvestment, and rejuvenation," respectively (ibid., 23). 
Based on current literature, it seems that different experiences of neoliberal urbanism share similar features. They include politico-economic elites determining policies in the public realm (Murphy, Fox-Rogers, and Grist) and the state facilitating privatization and marketization which conditions varieties of spatial strategies (Larner, Le Heron, and Lewis). In addition, neoliberal urbanism can be all encompassing. It can be the political rationality of governmental discourses and practices associated with cities (ibid.). The processes of neoliberalization can also penetrate the most local level possible (Rankin and Shakya). In East Asian or post-socialist cities, neoliberal urbanism is related to the state patronage system (Park and Saito; Büdenbender and Zupan), yet the logic of making an investment-friendly environment in cities remains intact.

Home, the other focal concept in this paper, is a fundamental aspect of human existence. Home, as spatial experience, is "an irreplaceable center of significance" (Relph, 39) which qua dwelling (Heidegger) "involves the process by which a place in which we exist becomes a personal world" (Seamon and Mugerauer, 8). The dwelling is constitutive of the subject's relation to the objective world as manifested in her spacing (Harrison). In other words, the dwelling as a home belongs to "us" and marks out a space for "us" (Jacobson). To be at home involves having practical knowledge of the situation and knowing how to act (Dekkers). It means to "stay among things and locales" (Heidegger, 359). In contrast to alienation, it means being fully present in one's milieu and having significant interactions with it. Home can also go beyond its usual meaning as an intimate subjective experience of space. It could entail the "social, psychological and emotive meaning for individuals and for groups" (Easthope, 135). With this in mind, the home's "external conditions ... [for] acting and living" (Olivier, 15) become important for grasping the totality of its subjective meaning in a given place for a given group.

By incorporating the appropriation and appreciation of the built environment into the concept of home, it refers to a larger geographical scale as its "loci of meaning" (Cuba and Hummon). Here, external conditions of being at home comprise characteristics of the physical and social environment, such as spatial quality (Stedman) and the availability of local amenities (see King 2005, 2008, 2009). Whereas housing can be understood as a physical construct (a shelter), the home is a social construct, as it gives meaning to the aforementioned concepts through human interaction. Home can be considered as a social space where several social sub-groups struggle to sustain their own mode of thinking and doing within the existing power hierarchy implying "a great diversity of knowledge" (Lefebvre 1991, 73). From this perspective, home is "at the hub of a whole complex of relationships" and "the crucial medium" 
that reveals people's lived spatial experience within the context of power relations within society (Saunders and Williams, 84).

This research attempts to understand the incongruities between what is usually called housing policy and what people consider their homes (in the broad sense) in the urban fringe of Tehran, the capital city of the Islamic Republic of Iran. We focus in particular on one county in the urban fringe: Shahriar, with approximately 745 thousand inhabitants as reported by Statistical Center of Iran. First, we analyze the development of spatial planning and housing policies, their legitimation and socio-spatial outcomes since the Islamic Revolution of 1979. Second, the subjective understanding of home is investigated through narrative interviews with residents of Shahriar. Based on qualitative results, we explain how the lived experience of home is affected by the aforementioned policies.

The role of the fringe in the urban fabric in general and its position in Tehran in particular has received increasing academic attention, as spatial planning and housing policies have pushed the urban poor to the outskirts of the city (Athari). Against the background of the Islamic Revolution's goal of "housing the poor" (Khatam and Haas, 5), it is surprising that the needs of the urban poor are not recognized in official spatial planning- and housing policies (Athari). This article attempts to understand the alarming housing situation of the urban poor in the urban fringe, despite the revolutionary propaganda about the protection of "the oppressed (mostaz'afin)" and even the allocation of large amounts of land for affordable housing during the first years after the revolution (Salek, 25).

The case study of Shahriar, on the fringe of Tehran, brings at least two new insights into the academic debate about urban planning and inequality. First, it contributes to our understanding of the relation between housing policy, segregation, and the lived spatial experience of home (Brenner and Theodore 2002). Deprivation of the residential environment might not only hamper one's life chances, but also place attachment, pride and feelings of home. However, this is strongly dependent on social cohesion in these communities (Long). Second, it contributes to our understanding of the nature and outcomes of neoliberal policy frameworks outside the Western context (see Brenner, Peck, and Theodore). It seems that, globally, planning practice has become more commercially oriented. The speculative form of urban development that is increasingly followed by private and public actors (Shatkin) can be positioned within the wider ideology of neoliberal urbanism and the associated institutional changes (Brenner and Theodore 2005; Jessop; Peck, Theodore, and Brenner 2009, 2013). However, neoliberal urbanism does not have the same 
appearance across the globe, as new modes of regulations interact with the local culture and path dependent local institutions. For the Iranian case, this means that the new strategic and comprehensive "entrepreneurial practices" (Vaziri Zadeh, 218) did not replace previous forms of regulation, but should be considered as additions to them (Madanipour).

\section{Theoretical Framework}

This paper is about spatial experiences being shaped by spatial plans in Shahriar County. Understanding how the state produces these spaces, how spatial experiences have been shaped in the framework of state planning for housing and urban development, and the grand spatial narratives during the post-revolution period are the objectives of this research. Therefore, the conceptual form would be two narratives of the same spatial phenomenonShahriar County. One is produced by the state, which is about planning and legislative actions. The other belongs to the inhabitants, a narrative as it is the after-effect of the grappling with such plans and policies.

Narrative shows how an event becomes meaningful over the course of time. In other words, the the event as it is experienced is the purpose of narrative. Accordingly, the essence of narrative is to reveal a hidden message by creating a chain of events (Shenhav), illuminating the subjective-epistemological side of a phenomenon. Therefore, it is possible to use narrative in an analytic context (ibid.). Narrative is the production of text determining the history of a concept through series of actions (from the personal to the institutional). Within these actions, different spaces are produced (de Certeau, 79) in which some actors could have the upper hand in power relations vis-à-vis the others.

Lefebvre's theory of the state mode of production (SMP) and his theory of the production of social space (Lefebvre 1991, 2009) are about establishing relations between different spaces. In Lefebvre's theory of social space, the conceived space, the space of urbanists, urban designers, and planners, hegemonizes the space of everyday dwellers (idem 1991). This (narrative) space bears spatial syntaxes which "by means of a whole panoply of codes, ordered ways of proceeding and constraints, they regulate changes in space" (de Certeau, 115). Therefore, what happens to space, on the part of the state, is never neutral (Harvey 1989, 239). Consequently, narrative is constitutive of our understating of space (Baynham).

It should also be emphasized that although implications of concepts such as neoliberal urbanism and creative destruction are used in this paper, theoretical prominence is given to Lefebvre's theory of the SMP, since it makes it possible to investigate both the production of conceived space and state spaces 
simultaneously. Moreover, the SMP theory is the ontology and source of later theory of neoliberalization (see Brenner).

\section{Planning, Ideology, and the State}

At first glimpse, Iran does not match the ideal-typical description of neoliberal urbanism. First of all, the state ideology is conservative-Islamic rather than (neo-)liberal. Second, the state intervenes deeply in the economy and has (at least on paper) a planning monopoly (Mojtahedzāda). Third, the built environment in Iran is barely financialized. However, planning practice has very much an entrepreneurial outlook, as speculation in land is the cornerstone of most developments (Vaziri Zadeh). To explain the housing situation of the urban poor in Iran, alongside the market, an understanding of the state is needed. Lefebvre (2009) conceptualizes the active role of the state in generating urban uneven development as the SMP. As he argues, the modern state has a very active and dynamic relation with space (ibid.). Spatially, the state is taking benefit of and dominating the agglomeration economies and the directing relations of production and of property. Through its ideology of technocratic rationality, the state mobilizes the production of space. It also realizes and allocates the surplus value (ibid.). The SMP implies "the production and continual modification of the socioterritorial infrastructures for successive historical regimes of capital accumulation" (Brenner, 792).

Expounding Lefebvre's SMP theory, Brenner deems neoliberal urbanism as a new face of the SMP. The state takes an active role in financing, subsidizing, and regulating capitalist growth through the commodification of the country's land through its historically specific institutional design. In practice, Peck, Theodore, and Brenner (2009) argue, neoliberal forms of social and spatial policy strengthen already advantaged locations, and ignore disadvantaged locations. This results in uneven geographical development, "realized across an uneven institutional landscape" (ibid., 51).

To understand how institutions shape the current patterns of uneven development, it does not suffice to take into account policies alone. Lefebvre understands institutions through the role of mediations within "social space." These mediations are "the action[s] of groups, factors within knowledge, within ideology, or within the domain of representation" (idem 1991, 77). In this research, mediations are understood as ideologies within society, discourses within the policy domain, and decision-making capacity. Together, they form the power structures that orientate social space within a predefined epistemological framework.

Lefebvre's general term or concept of the spaces produced by planning and the epistemology of planning was conceived space (ibid., 39-44). It is the space of urban planners, architects, and urbanists. This space provides a set of 
epistemological suppositions for the sake of "social harmony," which means nothing less than the continuation of "social reproduction under capitalism" (Harvey 1985, 177). In this perspective, planning becomes a conservative activity lubricating the neoliberal ideology to move smoothly within the fabric of social space. Within a neoliberal production of space, planning draws on competitive market logics (Gunder) which necessitates its institutional forms (Peck, Theodore, and Brenner 20og; Peck and Tickell).

As stated, this paper is about two narratives of the space: one which the planner or the urbanist creates (institutional/conceived space) and the other manifested in people's everyday lives as in their lived space or being at home (see Thompson-Fawcett). As in the case of Tehran, the chasm between the core of the city and its fringe is primarily manifested and rooted in the citycountry divide, which, in urban policy makers' attitudes, demands a different approach to space (Wachsmuth). Planning as an agent of forming conceived space (Lefebvre 1991) is tied to the order it produces or imposes upon lived space (see Soja, 67). Planners' conceived space, in Lefebvre's view, is the space of segmentation and separation (see Ronneberger, 137). In this paper, planning as a common noun signifies the apparatus of production of the state's spaces. It contains the policy-making process of producing spatial plans, which involve many parties and specialties. In final analysis, planning as a practice is manifested in administrative projects and planning documents.

\section{The Notion of Home}

To turn a house into a home, one needs to have a sense of belonging and attachment (Cresswell 2013). Moreover, this sense is not confined to a house or a shelter; it includes the wider geographical context. In the tradition of humanistic geography (see Cresswell 2004, 2013; Tuan), the earth becomes our home, the very moment we transform it "at a myriad of different levels" (Cresswell 2004, 24). Inspired by Norberg-Schulz and Bachelard, Relph argues that the sense of home is based on one's experience of the city at large, and the experience of one's immediate environment, consisting of the dwelling and the neighborhood. As both the city as a whole and the immediate environment are transformed by the SMP, it is essential to explore how variegated models of (neoliberal) governance impact upon the experiences of home in various living conditions.

Home as a "rich territory to understand the social and the spatial" (Domosh, 276) means it can be both meaningful and signifying phenomenon. Based on Lefebvre's formulation of lived space (1991), it is teemed with "sensual intimacies" (Soja, 30). Home is the lived space of everyday life being imposed and claimed by the conceived space. Different meanings of space are understood through different narratives of space. Therefore, understanding home 
inevitably requires us to look for narratives and stories of place. They are inseparable. Stories about place describe the organization of places. They allow us to specify "elementary forms of practices organizing space" (de Certeau, 116). Stories "carry out a labor that constantly transforms places into spaces or spaces into places" (ibid., 118). Narratives are about different ways spatial knowledge and spatial lived experience order space. Spatial stories are about how different coexistences and juxtapositions are practiced. (see ibid., 129-30). Narratives make the relation between spatial experience, personal identity, and subjectivity manifest (Schlitte). These can be told either by planners or by people living the spaces. From this perspective, narratives have an ontological significance, since they can transform the environment.

Today's process of neoliberal city-building is characterized by placelessness (Relph; Shields), as the most generic urban form can be turned into an asset that is tradable on global capital markets. However, practices of city building "modify the everyday spaces" (Stanek, 84). These practices "extend to commercial, health, educational, social, and administrative services" (ibid., 83). Accordingly, understanding "multiple scales of social processes" (ibid., 86) such as the state mode of production, and the associated commodification of space enable us to trace the narratives of institutional, ideological and discursive streams that shape the modern neoliberal city.

\section{Materials and Method}

The archival data consist of spatial plans and housing policies from different administrative levels, published between 1982 and 2017, affecting the housing conditions in Shahriar County. These policy documents are analyzed on the basis of their ideological orientation, the role of the state, the market, the family in housing production, and the (location of) proposed spatial interventions.

Semi-structured interviews were conducted with fifty-eight residents of Shahriar County who have resided in the county for more than two years at the time of the interview in 2017 (Table 1). Older residents were of greater interview interest, as they are expected to have a better overview of the history of the county and its social stratification. Respondents are selected at locations where the population of Shahriar gathers: major avenues and marketplaces. Interviews lasted from thirty to sixty minutes, were digitally recorded, and were transcribed verbatim. Before the start of the interview, the respondents were briefed about the concept of home used in this study, including the surrounding environment. All questions were formulated in an open fashion to allow the respondent to elaborate on his or her life world, resulting in rich data. Respondents were requested to recall their place of 
TABLE 1 Demographics

\begin{tabular}{llr}
\hline Gender & Male & 33 \\
Age & Female & 25 \\
& $<20$ & 7 \\
& $20-35$ & 26 \\
& $35-45$ & 17 \\
& $45^{-60}$ & 3 \\
Education & $>60$ & 5 \\
& Primary & 11 \\
& Secondary & 12 \\
Status of Employment & High school & 12 \\
& University & 23 \\
Migration & Employed & 39 \\
& Unemployed & 19 \\
& Local & 16 \\
Total & First Generation & 15 \\
& Second Generation & 27 \\
& & 58 \\
\hline
\end{tabular}

residence in order to give the interviewers their first associations and impressions related to the question. They were asked how they experience their place of residence, work, and recreation. Furthermore, they were asked to assess the public space (e.g., market places and avenues) and the accessibility, availability, and affordability of amenities (e.g., sanitized water, appropriate schooling, transportation, and shops). Following questions about their place of residence, respondents were asked to describe what they consider their homes and to what extent they consider their place of residence as their homes. The transcribed interviews were analyzed using manual coding to extract the main theme for interpretation (see MacKian). These themes were subsequently translated into narratives (see Smith and Osborn).

\section{Reading the Archive}

\section{Spatial Planning Policies after the Revolution}

The nature of urban growth in Shahriar County, located in Tehran's western fringe, is strongly related to the history of spatial planning and housing policies in Tehran's metropolitan area, and Iran in general. The development of 
Shahriar County is unique: between 1967 and 2015, the population size of the urban fringe increased with a factor of 2.5 (Ghaedrahmati and Ahmadi Nuhadany). At the same time, Tehran was growing westward (Madanipour). Shahriar County therefore developed into one of the main urban areas within the metropolitan area. Compared to Tehran, Shahriar is socio-economically disadvantaged (Amirahmadi and Kiafar; Shirazi). However, within Shahriar, high levels of socio-spatial inequality exist. Especially in the outskirts, one can find a concentration of deprived households. Among the eight counties on the fringe of Tehran, Shahriar absorbed the highest number of immigrants between 1996 and 2016 (on average of 24 thousand each year), as reported by the Statistical Center of Iran. For migrants, Shahriar County has a strategic location within the Tehran metropolitan area (Shirazi), allowing them to tap into the high economic growth rate. However, the consequences of uneven development confront migrants with a reality contrary to their hopes and expectations. An overview of the institutional changes explains the degree and nature of uneven development.

After the Islamic Revolution, National Development Plans (NDPs) have guided the spatial development of Iran. Gradually, these plans have laid the foundation for a more pronounced and more speculative role of the state in the production of space. With regard to housing and urban development policies, some major spatial planning laws were passed during the first years after the Islamic Revolution. These aimed mainly to reduce housing prices for the working class. The government established a planning monopoly, which allowed it to take control of land provisioning and construction. The Urban Land Code (ULC, Qānun-e zamin-e shahri) is one of the most important instruments used to achieve the construction of more affordable housing. Passed in 1982, the law mandated a period of time in which owners of land adjacent to legal city boundaries could commence construction or renovation of existence buildings before the state would expropriate their land (Tarh-e jāme $-e$ maskan). This was the first major step by the state to gain a monopoly in urban management and planning in the urban fringes of the metropolitan areas. Following the Iran-Iraq War (1980-88), the government adopted another legal approach for land management: the NDPs, which determine developments in the social, political, economic, and cultural realms for a five-year period.

The first (1990-94) and the second (1994-99) NDPs had two general directions. First, they aimed at allocating "greenfield" and "brownfield" lands for affordable housing intended for lower income groups. Second, the land provision for new satellite towns around the larger urban centers was put at the center of the agenda. The first two NPDS allowed the government to expropriate a large amount of land in order to control and regulate housing and urban 
development (ibid.). During the first and the second NDP s, the state became an agent in regulating, producing, and mobilizing space without trying to privatize it. Therefore, these plans can be considered a non-neoliberal form of the state mode of production.

During the third NDP (2000-4), the government started to organize the supply of land for development based on the market value. Simultaneously, the state started to privatize part of the national land reserve and revoked the tax on barren land. These measures are conditions for the marketization of land, which in turn increased urban land values since 2006. The fourth NDP (2004-9) continued the aim of restructuring the decaying parts of the urban fabric and the management of informal settlements (Tarh-e jāme-e maskan; Sanad-e talfiq). Compared to the first two NDPs, the third and fourth NDP s have increased the importance of private property and the role of market actors in spatial planning. Although the state remains the dominant force in spatial planning, the SMP has a more neoliberal outlook. On various scale levels, the state is a major land owner and developer, profiting from increasing values.

During the fifth NDP (2010-15), the government attempted to remove the land price from the cost of housing through the public provision of land (Zahmatkash and Ahmadi). At first, it seemed like a return to the old situation. However, a more detailed analysis shows that the commodification of space continued in order to incentivize private parties to invest in the built environment. Furthermore, it laid the foundation for the use of more advanced financial products to finance these investments, generally referred to as the financialization of the built environment (ibid.). In order to cope with the so-called informal settlements and unorganized residential areas, there were several articles in the fifth NDP that dealt specifically with the social and physical problems in urban fringe (ibid.). In order to motivate politico-economic elites, they aimed to foster participation in decision-making, and encouraged private actors to invest in these locations.

\section{Housing Policies after the Revolution}

The national development plans set the framework for housing production after the Islamic Revolution. However, these plans have increasingly become an obstacle in the provision of affordable housing due to their speculative outlook. Therefore, a new housing policy has been initiated. The National Housing Comprehensive Plan 2014-2026 (N HCP) enumerates four major problems challenging the Iranian housing market. First, high land prices obstruct the construction of affordable housing. Second, several policies are not upheld, rendering them ineffective. Third, the increasing amount of informal construction reduces quality and access to amenities. Finally, the housing market is 
deemed unstable due to price volatility (Sanad-e talfiq). The above-mentioned problems are partly caused by the Iranian practice of demarcating urban versus non-urban land. Only the land that is classified as urban is eligible for receiving urban facilities, infrastructures, and amenities (Zebardast). However, the solution for the housing crisis was found in increasing lower income groups' access to mortgage. It is reasoned that the development of financial instruments for the purchase of owner-occupied housing and hire-purchase is an incentive for the private sector to invest in housing (ibid.).

Intending to provide low-income people with housing units through free land and cheap credits, Mehr housing projects (Figure 1) are emblematic of Iran's contemporary social housing scheme ("Tehran Mehr Housing"). Their major aim is to prevent the growth of informal settlements in fringes of cities. Their secondary aim is to absorb the overpopulation of Tehran's metropolitan area. By removing the land price from the actual costs of housing, the scheme is able to provide affordable housing in the homeownership segment. So far, nearly 1.8 million apartment units around the country have been built, of which Shahriar County constitutes approximately three thousand units,

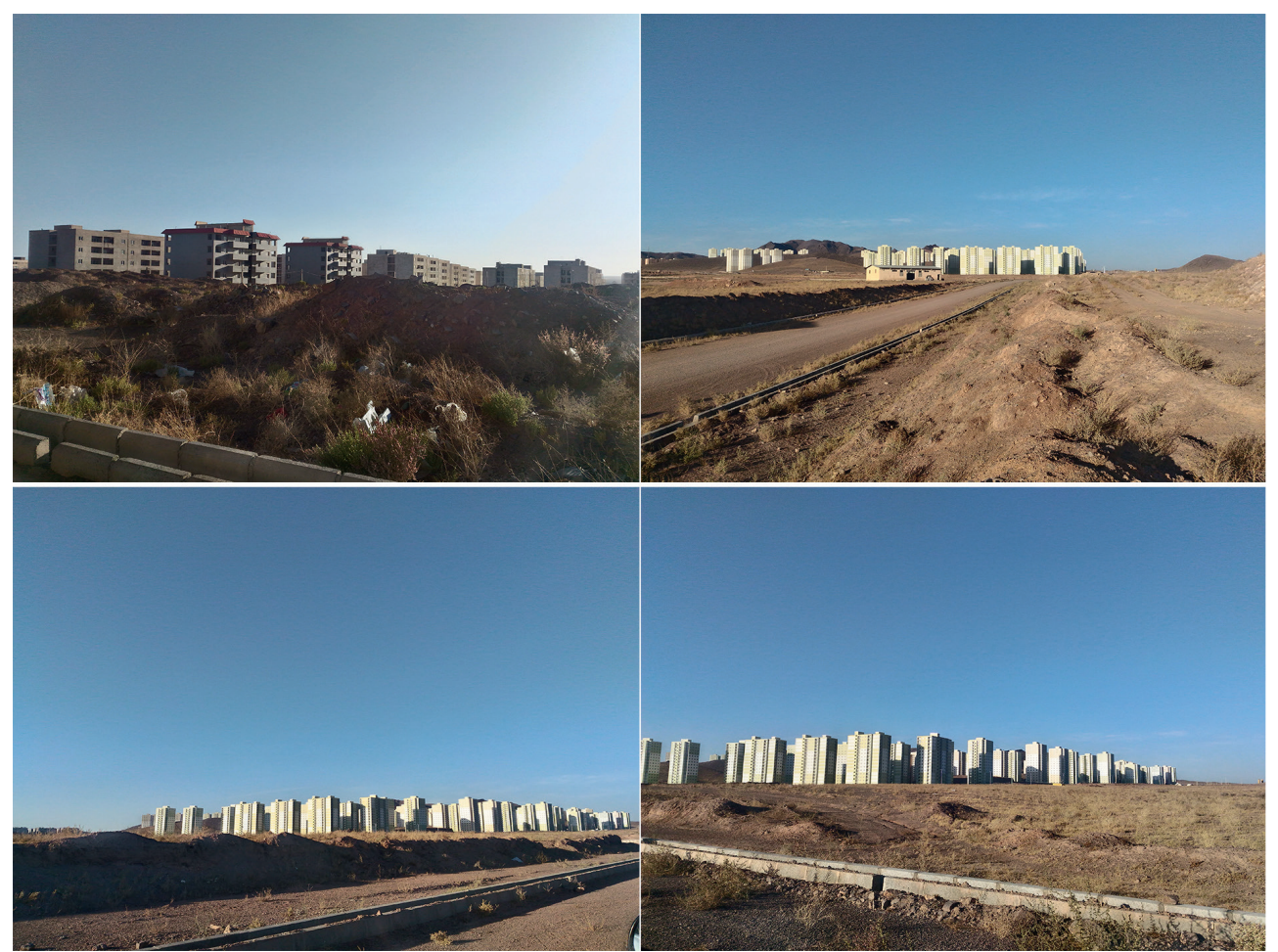

FIgURE 1 The Mehr Housing Project on the fringe of Tehran SOURCE: AUTHORS 
concentrated in Andisheh (a city in the county) (Goruh-e motālle'ät-e Sherkat-e rahpusākht-e Shārestān). The Mehr housing projects' geography is particular: they are constructed primarily on the remote edges of the urban fringe ("Vazir-e rāh"). The concentration of Mehr housing on the urban fringe can be understood from their close proximity to informal settlements, the problem that the projects aim to tackle. The choice for the periphery of the fringe is motivated by an economic factor: lower land prices. Furthermore, planning social housing in the fringe generates room for higher-yielding investments at central locations. The Mehr housing projects are planned as housing market intervention only. They are dormitories rather than vibrant social or economic communities ("Ma’muriyat-e motefāvet").

\section{Segregation qua Seclusion and Remoteness}

The semi-structured interviews reveal one meta-narrative about the experience of home in Shahriar: segregation qua seclusion and remoteness shapes the understanding of one's socio-spatial positioning. It is a meta-narrative of limited access to amenities, decision-making, and social life. Together, seclusion and remoteness comprise the subjective and objective dimension of segregation. Four subthemes divide the main arguments why residents feel secluded and remote.

\section{The Edge of the World}

For Shahriar's inhabitants, the county is located at "the edge of the world," far away from amenities, life chances, and leisure. The physical dimension of seclusion and remoteness is prominent when visiting Shahriar (Figure 2). The phenomena that meet the eye while entering Shahriar County from Tehran are empty lands, incomplete buildings, and residential complexes. The city of Shahriar, the seat of the eponymous county, is a miniature emulation of Tehran itself, mimicking even the name of Tehran's major roads such as Vali'Asr Avenue or Enqelāb Street. The city's core is distinctive from the rest of the county. Its bazaar is very dynamic and hectic during weekdays. It contains shops with classy display windows along with famous restaurants and coffee shops. More remote locations in Shahriar are characterized by desolate wastelands and unfinished construction. The eye finds the emptiness of land parallel with the emptiness of the soul (Figure 3).

Many respondents point at the lack of amenities in Shahriar's outskirts, such as playgrounds, parks, and leisure facilities. Some explicitly connect the emptiness of the area to a lack of social cohesion and social control, allowing 
youngsters to take control of abandoned buildings as a form of self-provisioning of leisure facilities. A forty-nine-year-old woman describes the situation:

People start building, but then run out of money and cannot finish it because building materials become more expensive every day. Some of them are government projects and are left after some time, we don't know why. Some of them are really far away from both Tehran and Shahriar. They turn into hangouts for children and juveniles. My fourteen-year old son goes there to play with his friends. They burn tires and look at the smoke or snap loudly in the empty, half-finished building to hear the echo. I wish we had a park here.

Parents in particular are concerned about the material living conditions of their children, as neither public nor private leisure facilities are available in the outskirts of Shahriar. Moreover, the above quotation reflects a sense of acquiescence with the current situation, in which residents see the abandonment of state-initiated building projects as an act of general neglect of the area. The comments of some of the respondents underline that a part of Shahriar is planned to provide shelter for lower income groups, rather than as a place to feel home. In the words of a forty-five-year-old man, residents with a low income are locked into their location:

We have no decent urban services, no nothing here. My daughter has to take a forty-five-minute walk every day to her school. Here, there is no public transport. We have water outages two times a week. We are on the edge of the world: it's like Mehr housing [see Figure 1]. Only those who are financially unable to buy or rent anywhere else chose the edge or the outskirt to live.

For some of the respondents the link between the low socio-economic status of the residents and the low spatial quality of the environment was significant. A fifty-eight-year old housewife gives the following account:

We have no market around here [in Shahriar's outskirts]. If we want to buy some clothes or something other than food, we have to go to [the city center of] Shahriar. We lack sanitized water, a hospital, school, library, and many other things. Many of children's parents are workers ... A good cultural and recreation center is needed here. I think it's the end of the world. 


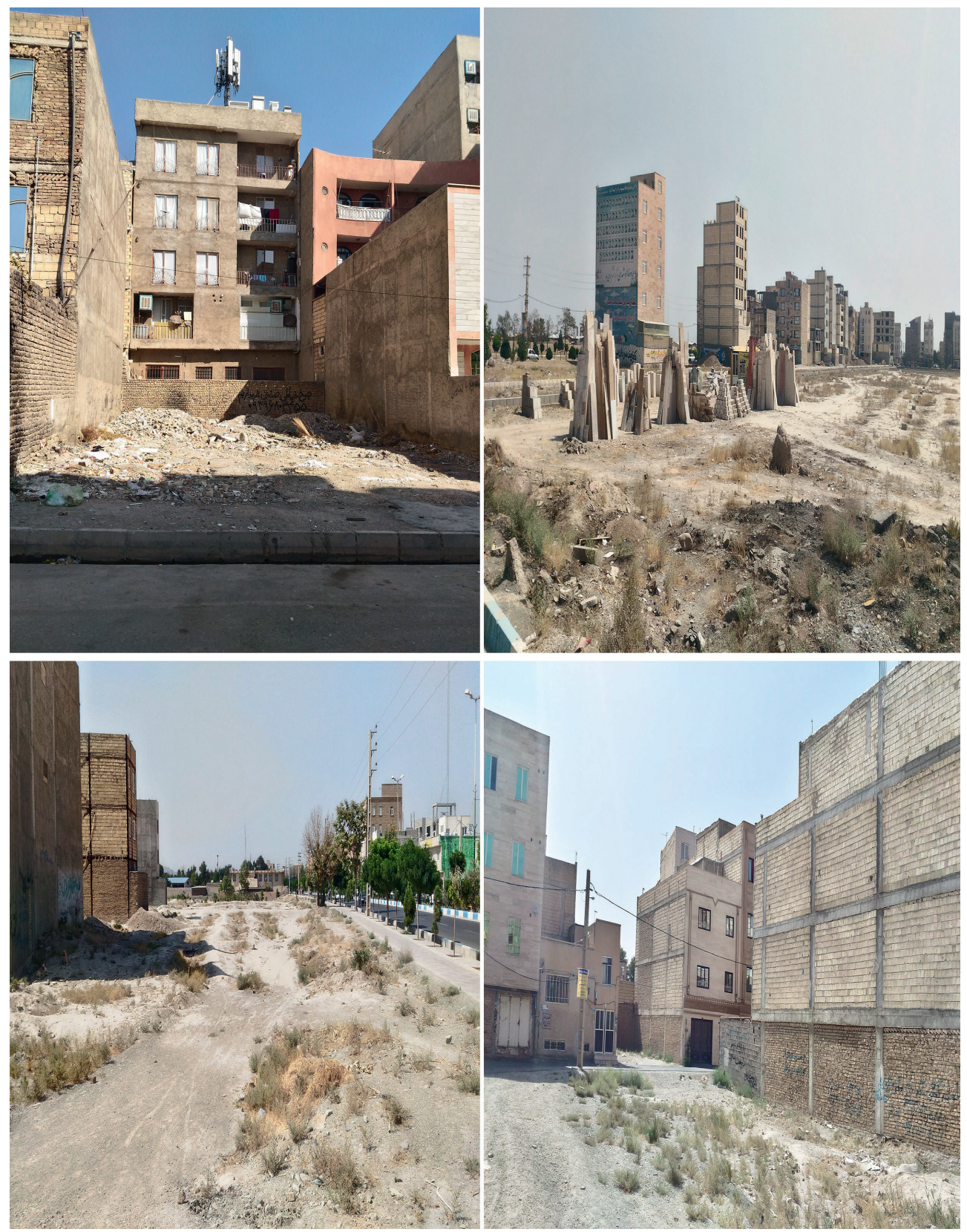

FIGURE 2 Empty lands, incomplete buildings, and residential complexes in Shahriar County SOURCE: AUTHORS 


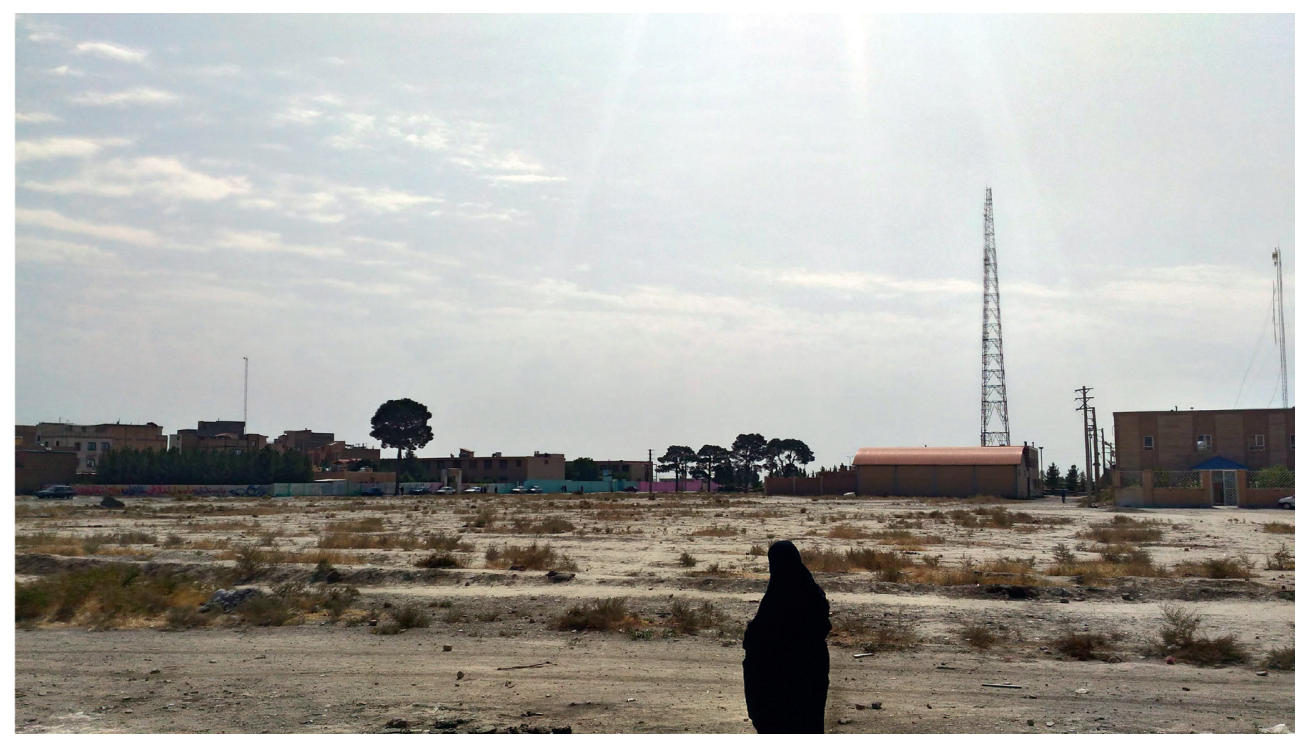

FIGURE 3 A woman looking at a conspicuously empty land in Shahriar County SOURCE: AUTHORS

In her words, she indirectly does not consider her place of residence as Shahriar but a nameless place referred to as "here." Phrases such as "end of the world" and "edge of the world" are often used to describe this situation in Shahriar. The phrasing explains a lot about the emotional life of the people who make these statements. The world represents the happy (middle-class) life that is impossible to attain under the current circumstances. The use of "end" and "edge" illustrates that respondents have the idea they cannot move out to different locations to enter this "world of happiness."

\section{Uninterested Municipality}

Shahriar's disadvantaged position is the direct outcome of spatial planning policies. The entrepreneurial approach to planning has encouraged public authorities to invest in profitable locations, pushing low-income households to the urban fringe. The residents of Shahriar County live with the consequences: they live in an area that barely receives public funding. The respondents repeatedly point to a lack of attention of the local authorities for disadvantaged areas in the outskirts of the urban fringe.

For the residents of Shahriar, the urban fabric represents the power structure in society. The residents of Shahriar's outskirts are able to discern the palatial gardens and villas built for Tehran's elite. Only a strip of barren land 
separates these neighborhoods. A man (thirty-three years old), earning a living by driving his taxi says:

These glorious gardens and villas aren't ours. They belong to the rich people from Tehran who pay for their construction permits. If you pay the money, the municipality allows you to build anything. No rules prevail here, money says the last word.

The above-mentioned respondent connects the approach followed by the municipality, as a public organ directly dealing with spatial affairs, which in their words, increases socio-spatial inequality. He refers to the common practice of municipalities to "sell" construction permits for new housing or extensions to existing dwellings. Previous research points out that many municipalities are very lenient regarding the provision of these permits, as they are one of the main sources of income (Zanganeh Shahraki and Hosseini). It is well-documented that this practice has reinforced sociospatial problems such as air pollution, traffic congestion, and eventually urban crimes in these densified neighborhoods (Pourmusavi et al.). Even authorities in the Ministry of Road and Urban Development describe it as "the curse of density selling" ("Nefrin-e tarākom-forushi"). In the public media, density selling is ironically defined as "selling the sky of the city" ("Forush-e āsmān-e Tehrān").

A repeating pattern in the answers of the respondents reveals the ideological legitimation of the neglect of the urban fringe by the state. The respondents point out that the inhabitants of Shahriar are portrayed as undeserving (not productive and integrated). Rather than solving social problems or delivering services to the public, the municipality is viewed as only interested in maintaining a financially sound performance. A forty-six-year-old auto mechanic complains about the municipality. In his words:

Everybody is dissatisfied with the municipality here. The municipality doesn't care for its people. The only thing it knows to do is to sell extra floor construction permit. It's the end of the world. Nobody cares. It seems municipality doesn't pay attention to us because we cannot be a good source of income for it.

The residents of Shahriar's outskirts are doubly disadvantaged: they live Tehran's fringe and on the outskirts of that fringe. The poor concentrate in these locations, where they are invisible to the ruling élite and are put increasingly outside the scope for public interventions. As a result, the residents feel 
unwanted and forgotten. They live below the threshold of an acceptable life standard, excluded from public amenities, which causes them to abandon their hopes for a better life. These are the reasons why many of them considered Shahriar as "the place for the hopeless" or "the last resort for survival." A sixty-nine-year-old man characterizes the position of Shahriar's outskirts in the housing market of the wider region as follows:

Anyone who has no place else to go chooses this area for living. Anyone who is jobless and in despair chooses here to live, hoping to find a job and make life on scratch. I lost my sight when I was working at the spinning factory. Now I have to pay for my children's university. I couldn't find any place but here to live.

\section{Tehran as a Negligent Father}

The physical remoteness and mental seclusion of Shahriar's outskirts has an impact on the sense of home. For many, Shahriar is simply a workplace for commodity production for consumption in Tehran. They do not sense warm feelings in their place of residence. With this in mind, a thirty-four-year-old man says:

I have no significant memory of this place to tell you. Frankly, I just get out of the house at six in the morning and return on nine at night. I am a furniture finisher. I don't pay attention to anything. I just mind my way back and forth. This city is just a big workplace.

Some respondents produce goods in their homes or live in their production facility. They relate to Shahriar in the first place as "a big workshop." A fortythree-year-old man explains:

My workshop is on the first floor. I work with my two daughters and wife. It appears to be a city, but behind the surface, everybody struggles to live. We have no stable jobs. They turn this place into a city so they can have a municipality and have a share in the national budget. There is no advantage for us in it.

Few respondents mention the mutual dependency between Shahriar and Tehran. They view Shahriar as a production center for Tehran, where the final products are sold on the market. More than once, the relationship between Shahriar and Tehran is described as the relationship between a negligent father and his children. A thirty-three-year-old woman describes the inhabitants 
of Shahriar as children being economically dependent on "father Tehran," whereas Tehran only enjoys the work of his children, without giving any love in return:

Tehranis [the media, politicians, inhabitants] caused us to feel certain that we are a burden upon Tehran. Despite the fact that we are working for Tehranis and produce wealth for them. I don't feel at home here. Tehran is like a father to this place that forgot his children. Nobody knows what's going on here.

In national policy documents, the urban fringe is considered a problem: concentrated poverty in an informally built environment. The dominant discourse portrays the inhabitants of the urban fringe as a financial burden upon the better-positioned inhabitants (of Tehran), ignoring the economic interdependency between Shahriar and Tehran, and between the urban poor and the well-off. Whereas the well-off Tehranis are not confronted with the urban fringe during their daily life, the economic interdependency is a daily reality for Shahriar's inhabitants, who feel actively deprived by the authorities.

\section{Uprootedness}

A feeling of uprootedness is a key element in the respondents' minds. This should not come as a surprise as Shahriar is a "city of arrival." It has received the largest numbers of migrants of all counties in the fringe of Tehran. A fiftythree-year-old grocer who lives in Shahriar for over eighteen years explains why he does not feel at home at his current place of residence:

Actually, I miss my hometown. It was really green, but without employment. You can't call it home here. Thank God, I can make ends meet. Other than that we have no attachment to this place. I feel as if I have no roots.

Residents of the large-scale government-sponsored social housing projects do not display higher levels of place attachment. A thirty-nine-year-old librarian describes her perspective:

We hope that the Mehr Housing develops. We are satisfied to be the [legal] owner of a house and saved from vagrancy. But I really don't know if this place with too many apartments gets a nice and acceptable shape. Everyone from all walks of life is gathered here. No one knows the other one's background. We are like water lilies; our roots are in water rather than soil. 
Although feeling dissociated and estranged is a characteristic feature of modern metropolitan life (Simmel), it seems people in Shahriar, experience this in more intensive ways. The results point at least to three causes. First, the low status of the outskirts of the urban fringe hamper sense of belonging. As people leave the area when they can afford it, many residents do not want to invest in the area because they hope to leave eventually. Second, as Shahriar's outskirts are the least attractive part of the housing market in Tehran's metropolitan area, they have attracted a group of residents with nothing in common but their low socioeconomic position. From this perspective, urban social segregation denotes lack of social identity and befitting quality of social solidarity (Preteceille) which are ubiquitous in the region. Third, the urban fabric, with barely maintained public space does not create social cohesion among the residents.

The disadvantaged position of Shahriar and especially its outskirts is strongly related to changes in spatial planning and housing policy in the last two decades. The increased importance of the exchange value of land and residential properties (see Lebas and Kofman), rather than the use value, has legitimized a concentration of investment in the most profitable locations, at the expense of the quality of life in neighborhoods that entail the lowest segment of the housing market.

\section{Discussion}

In Tehran, as in many other great cities in the world, the difference between the central city and its often segregated surrounding is substantial in terms of deprivation and spatiality of the problem (see Musterd and De Winter). In traditional understanding of the term, socio-spatial segregation means overrepresentation of some areas and underrepresentation of some others in a given territory (see van Kempen). The situation is aggravated when the spatial segregation leads to political fragmentation (see Le Galès), not only between Tehran and the fringe but also between policy-makers-such as the municipality - in the fringe and their fellow residents. This is exacerbated by the sense of being abandoned at the edge of the world. Consequently, problems in suburbs or the urban fringe are not limited to those areas, but should instead be understood in the context of broader social, political, and geographical considerations. In a centralized state like Iran, where — unlike the West— the state intervenes constantly into matters of space - the regionalization of a city cannot happen without the mobilization of planning and land policy decisions on the national level, thereby maintaining the state's land hegemony, as suggested by the SMP theory (Keil). Therefore, it is impossible for one to perceive 
of local planning outside the over-arching hierarchy of state planning in Iran (see Āl Yāsin).

Conceptually, this research connects the institutional causes of segregation with the lived experience of "home" in low-status neighborhoods in the urban fringe. The case study of Shahriar County, located in Tehran's western edge, is used to shed light on residents' lived spatial experiences (see Shields). Similar to Marcuse's concept of "layered city" (2002a, 94-114), inhabitants' mentality in Shahriar is crystalized in their actions in and interactions with the city. They are experiencing transitions of spaces during their daily business. However, all of these spaces carries a substantial sense of otherness in relation to Tehran. Simultaneously, the new patterns of segregation during the postrevolution period provokes a sense of "territorial alienation or dissolution of "place'" (Wacquant, 226). This stirs up "territorial stigmatization" (see ibid.) which instantiates the experience of marginality in Shahriaris' sense of space. Historically, in many countries, after the process of industrialization, the urban poor or working class had lived the furthest from the city. Such is currently the case for Tehran. In this condition, the role of the state becomes increasingly important in defining the parameters of growth on the outskirts of the central city (Marcuse 2002b, 27). This makes the role of the state and the related institutions an important factor for explaining segregation (van Kempen, 42).

The institutional causes of segregation can be found in changes in spatial planning and housing policy that have taken place during the last three decades since the Iran's Islamic Revolution. Despite the state's claim to shield citizens from poverty and adverse housing conditions, it paved the way for the introduction of a neoliberal model of urban planning mostly after the Iran-Iraq War in order to increase economic growth. Gholamhossein Karbaschi, the former mayor of Tehran $(r$. 1990-98) bluntly stated, "[w]e should make Tehran so expensive that anyone who cannot afford it would leave it," (Asghari). This discourse has been put into practice through the privatization of land and the marketization of developer rights during the first half of the 199os. The new mode of governance has boosted urban growth in cities and counties located in the fringe of Tehran, but has as well resulted in the suburbanization of poverty and the ghettoization of Shahriar's outskirts (see Mollā-Esmāçili).

Whereas Iran's planning system is characterized by some scholars as neoliberal, it differs from the traditional Anglo-American neoliberal model, as the market ideology interacts with pre-existing institutional practices and discourses (from the Islamic Revolution onward). The Iranian neoliberal planning model is state-led. Already in the late $198 \mathrm{os}$ and the beginning of the 199os, the state commissioned new towns and large-scale residential complexes, involving major private investments (Jomepour and Ebrahimi; Htaminejad et al.). 
The state has laid out the foundation for the commodification of land in the third through fifth National Development Plans, encouraging the private sector to invest in the real estate. Furthermore, more recent policy changes, aiming at turning the population into bankable citizens, enable people to take out a mortgage to finance their housing consumption. The Iranian dream of home-ownership becomes increasingly financialized, whereas the state (as a major property owner) profits from increasing real estate values in the core urban areas. The changing spatial planning and housing policies impact upon social stratification which led to the emergence of a new class of real-estate bourgeoisie (Athari and Yazdani).

In the case of Shahriar, speculative behavior manifests itself in two ways. First, the disadvantaged position of Shahriar is the outcome of the uneven distribution of public resources, mainly directed towards the construction of profitable developments at profitable locations as the engine of economic growth. If the urban fringe receives investments, it is to provide infrastructure and amenities for luxurious forms of urban sprawls, awaiting rising house prices. Second, the municipality operates as a rent-seeking actor by issuing building permits to whoever pays. In the end, speculation on land values is a cornerstone of the government's approach to spatial planning, for example, through the redevelopment of brownfield sites or by encouraging growth through the issuing of public bonds for construction at a discounted price (Vaziri Zadeh).

Rent-seeking motivations are the main drivers of spatial development in Tehran, causing public authorities to ignore those qualities of the builtenvironment that represent no direct financial benefit. Furthermore, entire locales that are seen as unprofitable do not attract investments and gradually become a place of the last resort for those who can no longer afford a living in parts of the city that are well-integrated in global (capital) markets. For the inhabitants of Shahriar, living in the city is contrasted with staying "among things and locals" (Heidegger, 359) or being at home. For Heidegger (360), building is an activity to make the environment your own by "founding and joining of spaces." In Shahriar's outskirts, the built environment makes the inhabitants feel unwanted and secluded in a remote part of the metropolitan area of Tehran which is quite different from the founding and joining of different spaces in the Heideggerian sense. For people in Shahriar, space becomes language and experience (see Strohmayer). Their fundamental lack of meaning and connectivity with space as manifested in their spatial imaginaries (see Bieger) is expressed in their moods, enunciation, and articulation of their daily experience of home. These narratives show that they feel trapped at the edge of the world. The disjointed and segregated spaces in Shahriar are the ramifications of 
the dominance of land speculation. The rapid increase in land price in central areas of the metropolitan areas have caused a displacement of the poor from centrally-located areas and brought about a suburbanization of the poor. This process is reinforced by the construction of large-scale social housing at the locations within the metropolitan area with the lowest land values.

\section{Conclusion}

The development of neoliberal spatial planning takes place within "the wings of public policy" (Harvey 2005, 19) and is therefore heavily dependent on state regulations. In Iran, neoliberal planning practices have been materialized in different institutional scale levels, and represent "a mode of governance by elites" (ibid., 20). Harvey's notion of neoliberal urbanism fits within Lefebvre's (2009) conceptualization of the state mode of production, in which the spatial is equated with the political. Public bodies actively engage in speculative construction activities. However, the institutional conditions that have unchained the built environment as a source of income and wealth are similar to the West: the privatization, marketization, and financialization of space.

The uneven development of Tehran's metropolitan area and the disadvantaged position of Shahriar, in particular, are the direct outcome of the neoliberal, technocratic rationality of the state, its entrepreneurial behavior, and legitimizing ideology. Recent changes in the ideology of neoliberal planning have mediated and facilitated the current regulatory practice of the state. Various policies (NDPS, ULC, NHCP, Mehr housing projects) have paved the way for deepened private and public investments at central and profitable locations. Indirectly, these plans have contributed to the suburbanization of poverty. The social housing program aimed at tackling the shortage of affordable housing and informal construction is realized in remote locations with low land values, ignoring the needs of the population, and reinforcing the socio-economic segregation in the greater Tehran metropolis. In the marginalized outskirts of the urban fringe, the inhabitants feel unwanted, secluded, and enmeshed in a part of the world where there is no sense of belonging. Within the current speculative form of urbanism, planners direct their attention to a cost-efficient housing solution for the urban poor in the fringe, rather than the provision of a proper home. What we witness is more than a neglect of housing as shelter; it is a failure to acknowledge home in its different layers that constitute the being-in-world of Shahriaris' everyday life. 


\section{Acknowledgements}

We thank Dr. Arjomand, Dr. Lewental, and the anonymous reviewers for their helpful comments and suggestions.

\section{Bibliography}

A. Āl Yāsin, Tārikhcha-ye barnāma-rizi-ye towséa dar Irān, Tehran, 2013/1392.

H. Amirahmadi and A. Kiafar, "The Transformations of Tehran from a Garrison Town to a Primate City: A Tale of Rapid Growth and Uneven Development," in H. Amirahmadi and S. El-Shakhs, eds., Urban Development in the Muslim World, New Brunswick, 1993, pp. 109-36.

M. Asghari, "Tehran-e gerān az Karbāschi tā Najafi," Ruz-nāma-ye Sharq no. 3002 (o2 November 2017/11 Ābān 1396), p. 16; online: https://www.magiran.com/article/ 3656124 (accessed: og February 2019).

K. Athari, "Barnāma-gorizi va kāstihā-ye barnāma-rizi dar maskan-e kam dar-āmadhā," Fasl-nāma-ye eqtesād-e maskan 34 (2003/1382), pp. 28-45.

K. Athari, and F. Yazdani, "Burzhuvāzi-ye mostaghellāt: Kazh-kārkardi-ye jāméa, kazh-tābi-ye shahr," Cheshm-andāz-e Irān 48 (2008/1387), pp. 43-50.

G. Bachelard, Poétique de l'espace, tr. M. Jolas as The Poetics of Space, Boston, 1994.

M. Baynham, "Narrative and Space/Time," in A. De Fina and A. Georgakopoulou, eds., The Handbook of Narrative Analysis, Blackwell Handbooks in Linguistics, Malden/ Oxford, 2015, pp. 119-39, DOI 10.1002/9781118458204.ch6.

L. Bieger, "No Place Like Home; or, Dwelling in Narrative," New Literary History 46.1, (Winter 2015), pp. 17-39, DOI 10.1353/nlh.2015.0004.

N. Brenner, "State Theory in the Political Conjuncture: Henri Lefebvre's 'Comments on a New State Form," Antipode 33.5 (November 20o1), pp. 783-808, DOI 10.1111/1467-8330.00217.

N. Brenner, J. Peck, and N. Theodore, "Variegated Neoliberalization: Geographies, Modalities, Pathways," Global Networks 10.2 (April 2010), pp. 182-222, DOI 10.1111/j .1471-0374.2009.00277.x.

N. Brenner and N. Theodore, "Cities and the Geographies of 'Actually Existing Neoliberalism,", Antipode 34.3 (July 2002), pp. 349-79, DOI 10.1111/1467-8330.00246.

N. Brenner and N. Theodore, "Neoliberalism and the Urban Condition," City 9.1 (2005), pp. 101-7, DOI 10.1080/13604810500092106.

I. Bruff, "The Rise of Authoritarian Neoliberalism," Rethinking Marxism 26.1 (2014), pp. 113-29, DOI 10.1080/08935696.2013.843250. 
M. Büdenbender and D. Zupan, "The Evolution of Neoliberal Urbanism in Moscow, 1992-2015," Antipode 49.2 (March 2017), pp. 294-313, D OI 10.1111/anti.12266.

M. de Certeau, Arts de faire, tr. St. Rendall as The Practice of Everyday Life, Berkeley, 1988.

T. Cresswell, Place: A Short Introduction, Short introductions to geography, Malden, 2004.

T. Cresswell, Geographic Thought: A Critical Introduction, Critical introductions to geography, Chichester, 2013.

L. Cuba and D. Hummon, "A Place to Call Home: Identification with Dwelling, Community, and Region," Sociological Quarterly 34.1 (Spring 1993), pp. 111-31, DOI 10.1111/j.1533-8525.1993.tboo133.x.

R. F. Daher, "Neoliberal Urban Transformations in the Arab City: Meta-Narratives, Urban Disparities and the Emergence of Consumerist Utopias and Geographies of Inequalities in Amman," Environnement urbain 7 (2013), pp. 99-115, DOI 10.7202/ 1027729ar.

W. Dekkers, "Dwelling, House and Home: Towards a Home-led Perspective on Dementia Care," Medicine, Health Care and Philosophy 14.3 (2011), pp. 291-300, DOI 10.1007/s11019-011-9307-2.

M. Domosh, “Geography and Gender: Home, Again?," Progress in Human Geography 22.2 (April 1998), pp. 276-82, DOI 10.1191/o30913298676121192.

H. Easthope, "A Place Called Home," Housing, Theory and Society 21.3 (2004), pp. 12838, DOI 10.1080/14036o9o41002136o.

"Forush-e āsmān-e Tehrān dar ezā-ye bedehihā-ye shahrdāri," Eqtesād Niyuz (18 September 2014/27 Shahrivar 1393); online: https://www.eghtesadnews.com/fa/ tiny/news-104467 (accessed: og February 2019).

S. Ghaedrahmati and S. Ahmadi Nuhadany, "Tehran in Space of Management Political of Analysis Land Domain," Geographical Researches Quarterly Journal 31.3 (2016), pp. 93-102.

Goruh-e motālle‘āt-e Sherkat-e rahpusākht-e Shārestān: Arziābi-ye tarh-e maskan-e mehr, Tehran, 2014/1392.

M. Gunder, "Planning as the Ideology of (Neoliberal) Space," Planning Theory 9.4 (May 2010), pp. 298-314, DOI 10.1177/1473095210368878.

P. Harrison, "The Space between Us: Opening Remarks on the Concept of Dwelling," Environment and Planning D: Society and Space 25.4 (August 2007), pp. 625-47, DOI $10.1068 / \mathrm{d}_{3} 65 \mathrm{t}$.

D. Harvey, The Urbanization of Capital: Studies in the History and Theory of Capitalist Urbanization, Baltimore, 1985.

D. Harvey, The Condition of Postmodernity: An Enquiry into the Origins of Cultural Change, Oxfird/Cambridge, 1989.

D. Harvey, A Brief History of Neoliberalism, Oxford/New York City, 2005. 
H. Htaminejad, Z. Zamani, S. Hajinejad, and M. Ghazaie, "Pathology of New Towns in Iran," Scientific- Research Quarterly of Geographical Data 22.88 (Winter 2014), pp. $47-57$.

G. Haughton, The New Spatial Planning: Territorial Management with Soft Spaces and Fuzzy Boundaries, London/New York City, 2010.

M. Heidegger, Basic Writings: From Being and Time (1927) to The Task of Thinking (1964), ed. D. F. Krell, San Francisco, 1993.

K. Jacobson, "A Developed Nature: A Phenomenological Account of the Experience of Home," Continental Philosophy Review 42.3 (2009), pp. 355-73, DOI 10.1007/ s11007-0o9-9113-1.

B. Jessop, "Liberalism, Neoliberalism, and Urban Governance: A State-Theoretical Perspective," Antipode 34.3 (July 2002), pp. 452-472, D OI 10.1111/1467-8330.00250.

M. Jomepour and A. Ebrahimi, "The Measurement and Evaluation of the Components of Social Sustainability in Apartment Complexes," Urban Studies 5.16 (Fall 2015), pp. $1-30$.

R. Keil, "Extended Urbanization, 'Disjunct Fragments' and Global Suburbanisms," Environment and Planning D: Society and Space 36.3 (December 2018), pp. 494-511, DOI 10.1177/o263775817749594.

R. van Kempen, “The Academic Formulations: Explanations for the Partitioned City," in P. Marcuse and R. van Kempen, eds., Of States and Cities: The Partitioning of Urban Space, Oxford Geographical and Environmental Studies, Oxford/New York City, 2002, pp. 35-56.

A. Khatam and O. Haas, "Interrupting Planetary Urbanization: A View from Middle Eastern Cities," Environment and Planning D: Society and Space 36.3 (March 2018), pp. 439-55, DOI 10.1177/o263775818759334.

P. King, The Common Place: The Ordinary Experience of Housing, Design and the Built Environment, Aldershot/Burlington, 2005.

P. King, In Dwelling: Implacability, Exclusion and Acceptance, Design and the Built Environment, Aldershot/Burlington, 2008.

P. King, "Using Theory or Making Theory: Can There be Theories of Housing?," Housing, Theory and Society 26.1 (2009), pp. 41-52, DOI 10.1080/14036o9o802704296.

W. Larner, R. Le Heron, and N. Lewis, "Co-constituting "After Neoliberalism": Political Projects and Globalizing Governmentalities in Aotearoa/New Zealand," in K. England and K. Ward, eds., Neoliberalization: States, Networks, Peoples, Antipode Book Series, Malden, 2007, pp. 223-47.

E. Lebas and E. Kofman, "Lost in Transposition-Time, Space and the City," in H. Lefebvre, Writings on Cities, ed. and tr. E. Lebas, and E. Kofman, Oxford, 20oo, pp. 3-6o.

H. Lefebvre, La production de l'espace, tr. D. Nicholson-Smith as The Production of Space, Oxford, 1991. 
H. Lefebvre, State, Space, World: Selected Essays, ed. and tr. N. Brenner and St. Elden, Minneapolis, 2009.

P. Le Galès, "Urban Governance and Policy Networks: On the Urban Political Boundedness of Policy Networks: A French Case Study," Public Administration 79.1 (Spring 2001), pp. 167-84, DOI 10.1111/1467-9299.00251.

J. Long, "Sense of Place and Place-based Activism in the Neoliberal City: The Case of 'Weird' Resistance," City 17.1 (2013), pp. 52-67, Do I 10.1080/136o4813.2012.754186.

S. MacKian, "The Art of Geographic Interpretation," in D. DeLyser, St. Herbert, St. Aitken, M. Crang, and L. McDowell, eds., The SAGE Handbook of Qualitative Geography, London, 2010, pp. 359-72, DOI 10.4135/978085702109o.n23.

A. Madanipour, "Urban Planning and Development in Tehran," Cities 23.6 (December 2006), pp. 433-38, D OI 10.1016/j.cities.2006.08.002.

"Ma'muriyat-e motefāvet dar maskan-e Mehr," Donyā-ye-Eqtesād no. 4400 (14 August 2018/23 Mordād 1397); online: https://www.donya-e-eqtesad.com/fa/tiny/news -3426848 (accessed: og February 2019).

P. Marcuse, "The Layered City," in P. Madsen and R. Plunz, eds., The Urban Lifeworld: Formation, Perception, Representation, London/New York City, 2002a, pp. 94-114.

P. Marcuse, "The Partitioned City in History," in P. Marcuse and R. van Kempen, eds., Of States and Cities: The Partitioning of Urban Space, Oxford Geographical and Environmental Studies, Oxford/New York City, 2002b, pp. 11-34.

Mohäjerān-e vāred shoda tey 5 sāl-e gozashta beh tafkik-e shahrestān-e mahal-e eqāmat-eqablivafecli,Tehran,2016/1395;online:https://amar.org.ir/سرشمارى-/تتايجسرشمارى عمومى-نفوس-و -مسكن (accessed: og February 2019).

G. Mojtahedzāda, Barnāma-rizi-ye shahri dar Irān (Reshta-ye joghrāfiyyā), Tehran, 2008/1387.

'A.-R. Mollā-Esmāiili, Nābesāmānihā-ye jam‘iati-Kālbadi-ye shahri-e shahrestān-e Shahriyār, Tehran 1998/1377.

E. Murphy, L. Fox-Rogers, and B. Grist, "The Political Economy of Legislative Change: Neoliberalising Planning Legislation," in A. MacLaran and S. Kelly, eds., Neoliberal Urban Policy and the Transformation of the City: Reshaping Dublin, London, 2014, pp. 53-65.

S. Musterd and M. De Winter, "Conditions for Spatial Segregation: Some European Perspectives," International Journal of Urban and Regional Research 22.4 (December 1998), pp. 665-73, DOI 10.1111/1468-2427.00168.

“Nefrin-e tarākom-forushi, balā-ye jān-e shahrhā," Islamic Republic News Agency (17 December 2017/26 Âzar 1396); online: https://www.irna.ir/news/82766997 (accessed: og February 2019).

Ch. Norberg-Schulz, Existence, Space \& Architecture, New Concepts of Architecture, London, 1971. 
A. Olivier, "Understanding Place," in Br. B. Janz, ed., Place, Space and Hermeneutics, Contributions to Hermeneutics 5, Cham, 2017, pp. 9-22, DOI 10.1007/978-3-319 $-52214-2 \_2$.

B.-Gy. Park and A. Saito, "Concluding Remarks," in B.-Gy. Park, R. C. Hill, and A. Saito, eds., Locating Neoliberalism in East Asia: Neoliberalizing Spaces in Developmental States, Studies in Urban and Social Change, Chichester, 2012, pp. 294-302, DOI 10.1002/9781444346657.ch11.

J. Peck, N. Theodore, and N. Brenner, "Neoliberal Urbanism: Models, Moments, Mutations," SAIS Review of International Affairs 29.1 (Winter-Spring 2009), pp. 49-66, DOI 10.1353/sais.0.0028.

J. Peck, N. Theodore, and N. Brenner, "Neoliberal Urbanism Redux?," International Journal of Urban and Regional Research 37.3 (May 2013), pp. 1091-99, DOI 10.1111/ 1468-2427.12066.

J. Peck and A. Tickell, "Neoliberalizing Space," Antipode 34.3 (July 2002), pp. 380-404, DOI 10.1111/1467-8330.00247.

M. Pourmusavi, S. Zanganeh Shahraki, N. Ahmadifard, and N. Abdi, "The Effect of High Rise Buildings on Urban Crimes (Case Study: 22 Zones of Tehran)," Human Geography Research Quarterly 43.77 (Fall 2011), pp. 61-73.

E. Preteceille, "Collective Consumption, Urban Segregation, and Social Classes," Environment and Planning D: Society and Space 4.2 (June 1986), pp. 145-54, DOI 10.1068/do40145.

K. Rankin and Y. Shakya, "Neoliberalizing the Grassroots? Microfinance and the Politics of Development in Nepal," in K. England and K. Ward, eds., Neoliberalization: States, Networks, Peoples, Antipode Book Series, Malden, 2007, pp. 48-76.

E. C. Relph, Place and Placelessness, Research in Planning and Design 1, London, 1976.

Kl. Ronneberger, "Henri Lefebvre and Urban Everyday Life: In Search of the Possible," in K. Goonewardena, ed., Space, Difference, Everyday Life: Reading Henri Lefebvre, New York City, 20o8, pp. 134-46.

A. Salek, "Tehran, the History of Decentralization, 1800-200o," M. A. thesis, Utrecht University, 2007; online: http://dspace.library.uu.nl/handle/1874/25676 (accessed: o1 September 2020).

Sanad-e talfiq-e tarh-e jāme-e maskan (1393-1405/2014-26), Tehran, 2014/1393.

P. Saunders and P. Williams, "The Constitution of the Home: Towards a Research Agenda," Housing Studies 3.2 (1988), pp. 81-93, DO 10.1080/o2673038808720618.

A. Schlitte, "Narrative and Place," in Br. B. Janz, ed., Place, Space and Hermeneutics, Contributions to Hermeneutics 5, Cham, 2017, pp. 35-48, DOI 10.1007/978-3-319 $-52214-2 \_4$.

D. Seamon and R. Mugerauer, "Dwelling, Place and Environment: An Introduction," in D. Seamon and R. Mugerauer, eds., Dwelling, Place, and Environment: Towards a Phenomenology of Person and World, Dordrecht/Boston, 1985, pp. 1-12. 
G. Shatkin, "The Real Estate Turn in Policy and Planning: Land Monetization and the Political Economy of Peri-urbanization in Asia," Cities 53 (April 2016), pp. 141-49, DOI 10.1016/j.cities.2015.11.015.

Sh. R. Shenhav, "Political Narratives and Political Reality," International Political Science Review 27.3 (July 2006), pp. 245-62, Do I 10.1177/0192512106o64474.

R. Shields, Places on the Margin: Alternative Geographies of Modernity, International Library of Sociology, London/New York City, 1991.

M. R. Shirazi, "Sustainable Planning for a Quasi-Urban Region, Necessities and Challenges: The Case of Tehran-Karaj," Planning Perspectives 28.3 (2013), pp. 441-6o, DOI 10.1080/02665433.2013.774535.

G. Simmel, On Individuality and Social Forms: Selected Writings, ed. D. N. Levine, Heritage of Sociology, Chicago/London, 1971.

J. Smith and M. Osborn, "Interpretative Phenomenological Analysis," in J. A. Smith, ed., Qualitative Psychology: a Practical Guide to Research Methods, 2nd ed., London/ Los Angeles, 2008, pp. 53-80.

E. W. Soja, Thirdspace: Journeys to Los Angeles and Other Real-and-Imagined Places, Cambridge, 1996.

Ł. Stanek, Henri Lefebvre on Space: Architecture, Urban Research, and the Production of Theory, Minneapolis, 2011.

R. C. Stedman, "Is It Really Just a Social Construction?: The Contribution of the Physical Environment to Sense of Place," Society \& Natural Resources 16.8 (2003), pp. 671-85, $10.1080 / 08941920309189$.

U. Strohmayer, "The Event of Space: Geographic Allusions in the Phenomenological Tradition," Environment and Planning D: Society and Space 16.1 (February 1998), pp. 105-21, DOI 10.1068/d160105.

Tarh-e jāmé-e maskan-e ostān-e Tehrān, Tehran, 2006/1385.

T. Taşan-Kok, "Introduction: Contradictions of Neoliberal Urban Planning," in T. Taşan-Kok and G. Baeten, eds., Contradictions of Neoliberal Planning: Cities, Policies, and Politics, GeoJournal Library 102, Dordrecht, 2012, pp. 1-19.

"Tehran Mehr Housing to Conclude by March," Financial Tribune (o5 June 2017); online: https://financialtribune.com/node/65818 (accessed: o9 February 2019).

N. Theodore, J. Peck, and N. Brenner, "Neoliberal Urbanism: Cities and the Rule of Markets," in G. Bridge and S. Watson, eds., The New Blackwell Companion to the City, Wiley-Blackwell Companions to Geography, Malden/Oxford, 2011, pp. 15-25, DOI 10.1002/9781444395105.ch2.

M. Thompson-Fawcett, “Urbanist' Lived Experience: Resident Observations on Life in Poundbury," Urban Design International 8 (2003), pp. 67-84, DOI 10.1057/palgrave .udi.9oooog6.

Y.-F. Tuan, Space and Place: The Perspective of Experience, Minneapolis, 1977. 
"Vazir-e rāh: Maskan-e Mehr az avval eshtebāh bud," Entekhāb.ir (14 February 2014/25 Bahman 1392); online: https://entekhab.ir/ooocYU (accessed: og February 2019).

A. Vaziri Zadeh, "The Evaluation of State Involvement in Large-Scale Property-Led Regeneration Projects in Iran," in F. F. Arefian and S. H. I. Moeini, eds., Urban Change in Iran: Stories of Rooted Histories and Ever-Accelerating Developments, Urban Book Series, Dordrecht, 2016, pp. 215-29, DOI 10.1007/978-3-319-26115-7_16.

D. Wachsmuth, "City as Ideology: Reconciling the Explosion of the City Form with the Tenacity of the City Concept," Environment and Planning D: Society and Space 32.1 (January 2014), pp. 75-9o, DO I 10.1068/d21911.

L. Wacquant, "The Rise of Advanced Marginality: Notes on its Nature and Implications," in P. Marcuse and R. van Kempen, eds., Of States and Cities: The Partitioning of Urban Space, Oxford Geographical and Environmental Studies, Oxford/New York City, 2002, pp. 221-39.

M. Zahmatkash and S. M.-R. Ahmadi, eds., Rāhnamā-ye kārbordi-ye qanun-e barnāma-ye panj-sāla-ye panjom-e towse'a-ye Jomhuri-ye Eslāmi-ye Irān (1390-94) 2010-15), Tehran, 2011.

S. Zanganeh Shahraki and S. A. Hosseini, "Economic Management of a City, Placing Emphasis on the Local Tax and the Effective Variables whereof (The Case of the City of Tehran)," Journal of Urban Economics and Management 1.2 (Spring 2013), pp. 87-106.

E. Zebardast, "Marginalization of the Urban Poor and the Expansion of the Spontaneous Settlements on the Tehran Metropolitan Fringe," Cities 23.6 (December 2006), pp. 439-54, DOI 10.1016/j.cities.2006.07.001. 